\title{
A realização do espírito na natureza: um caso entre Tübingen e Berna
}

\section{The construing of the spirit in nature: a case between Tübingen and Berna}

\author{
Pedro Geraldo Aparecido Novelli ${ }^{1}$
}

\begin{abstract}
Resumo
$\overline{\text { Os escritos de juventude de Hegel são marcados pela influência da filosofia kantiana que ele considerava }}$ a filosofia de seu tempo. Apesar dessa característica passível de reconhecimento nos escritos juvenis de Hegel pode-se também perceber indícios de uma gradativa separação em relação ao pensamento de Kant. Nesse sentido, o objetivo do presente texto é a exposição das críticas do jovem Hegel sobre a perspectiva kantiana. $\mathrm{O}$ texto escolhido tem como tema a religião desde a ótica institucional e a popular. Para Hegel o dualismo dicotômico razão - sentidos traduzido na distinção excludente alma - corpo significa o empobrecimento da religião e de seu potencial transformador.

Palavras-chave: Moral. Eticidade. Entendimento. Emoção.
\end{abstract}

\begin{abstract}
The writings of Hegel's youth have suffered a great influence of Kant's Philosophy which he considered the philosophy of his time. Despite such feature that can be traced in young Hegel's writings, many signs of a growing separation from Kant's thinking can also be noticed. In this way this paper aims at indicating Hegel's early criticisms of Kant. The chosen text deals with the official religion and the folk religion. For Hegel the dichotomic dualism reason - senses translated into the excluding distinction soul - body implies the impoverishment of religion poor as well as of its transforming role.
\end{abstract}

Keywords: Moral. Ethics. Understanding. Emotion.

\section{Introdução}

A edição dos textos de Hegel pela Suhrkamp atribui o título de "Fragmentos sobre religião popular e cristianismo" (HEGEL, 1970) ao primeiro texto selecionado na coleção das obras do citado autor e o situa no período de Berna. A edição da Meiner Verlag (HEGEL, 1991), por sua vez, assume a primeira linha do texto como indicação de título e o coloca ao final dos estudos de Hegel, ainda em Tübingen. Essa diferença entre o possível local de redação do texto pode determinar o pano de fundo sobre o qual a questão tratada por Hegel seria entendida. Se a edição da Meiner Verlag, conhecida como edição crítica, for assumida como a abordagem mais precisa, então é viável estabelecer uma relação mais calorosa entre o texto de Hegel e o texto kantiano "A religião nos limites da simples razão" (KANT, 1992), publicado pouco tempo antes do período no qual Hegel pensa a religião popular. O texto kantiano teria sido publicado na Páscoa de 1793 e Hegel, segundo a edição crítica, tê-lo-ia lido e comentado durante suas férias de verão em Stuttgart no mesmo ano. Um aspecto importante em relação ao período de redação do texto hegeliano é que em Berna Hegel teria sofrido uma grande influência das questões políticas do momento

\footnotetext{
${ }^{1}$ Professor Doutor da Faculdade de Filosofia e Ciências da Universidade Estadual Paulista - UNESP - área de Educação Filosofia. Email; pnovelli@ibb.unesp.br
} 
daquela localidade. O período de Tübingen seria caracterizado pela perspectiva teológica, porém o texto em questão indica que os primeiros escritos de Hegel têm como tema a religião sem, no entanto, adotarem de forma limítrofe a postura teológica. É possível reconhecer nos referidos escritos a postura marcadamente política do jovem Hegel que via a religião como um dos meios pelos quais a vida humana seria estabelecida e estruturada.

Hegel inicia o texto com o reconhecimento da importância atribuída à religião, pois as sociedades se empenham para que seus membros, já em tenra idade, entrem em contato com a perspectiva religiosa e os momentos mais marcantes na vida de um indivíduo tem a presença da religião. "A religião é uma das mais importantes situações (Angelegenheit) de nossa vida." (HEGEL, 1991, p. 83).

Hegel indica que, na idade, adulta a religião é ensinada tendo como referência a natureza humana ameaçada pela imediatez e pela arbitrariedade. Essa ameaça afetaria a tendência natural para o divino, para o bem. Há aqui alguns indícios de que Hegel teria em mente o texto kantiano "A religião nos limites da simples razão", pois a imediatez remete ao conceito da moral como fato da razão, ou seja, é inerente ao ser humano. Contudo, a imediatez do bem inerente ao homem é algo a ser preservado e direcionado para que o arbítrio não o assuma e, desse modo, a religião possa conduzir a ação humana. "De fato, a razão dificilmente revela a si mesma em sua essência e seu efeito perpassa todas as coisas como uma leve camada que dá a cada inclinação e impulso sua própria coloração." (HEGEL, 1991, p. $83)$.

\section{Religião Objetiva ou Frieza do Entendimento}

A religião, para Hegel, não é unicamente conhecimento de Deus, conhecimento de verdades, apropriação da doutrina nem compreensão da história religiosa, pois isso poderia ser feito somente pela razão. Na medida em que a religião se pretende vivida por um povo e para um povo, então ela precisa fazer-se sentir e perceber na vida do povo. Se a religião pretende exercer alguma moderação sobre a sensualidade de um povo, ela precisa igualmente ser sensual. Não é pelo abandono ou simples negação da sensualidade que tal aspecto receberá uma compreensão e expressões diferentes. "A religião envolve o coração. [...] Se os motivos religiosos devem ter um efeito sobre a sensualidade, eles também devem ser sensuais porque num povo sensual a religião, ela mesma, também é sensual." (HEGEL, 1991, p. 84).

Por isso, Hegel reage contra a racionalização do natural que promova a supressão ou submissão do sensual, e isso permite considerar que o natural não pode ser tranqüilamente associado ao que tende para o mal. Nas palavras de Hegel, a razão não pode desconsiderar a sensualidade, pois ela somente se efetiva se como o sal, salga e como a luz, ilumina (HEGEL, 1991, p. 85 - Mateus 5,13). O espírito vive pela sua encarnação, pela assunção da natureza em si e de si na natureza. O natural não desaparece sob a religião 'verdadeira', mas recebe novo sabor e nova luz pela razão. A razão saboreia o natural e se saboreia também no natural e, ao iluminar o natural, lança concomitantemente luzes sobre si mesma. Não se pode deixar de reconhecer aqui traços, bem delimitados, de superação do dualismo que estaria presente em Kant.

Taxativamente Hegel vê o conceito de religião não como ciência de Deus ou consideração de temas correlatos, mas como algo de interesse do coração. (HEGEL, 1991, p. 85). A palavra coração é empregada de forma proposital para caracterizar a centralidade do sentir, da emoção. Novamente, trata-se de uma contraposição a Kant que manifesta seu desconforto para com as práticas religiosas marcadamente extrovertidas. "A verdadeira e única religião só contém leis, ou seja, princípios práticos de uma necessidade incondicional, necessidade de que podemos ter consciência e que reconhecemos, por conseguinte, como reveladas pela razão pura (e não de maneira empírica)." (KANT, 1992, p. 195). 
O coração faz com que a crença seja intensa e as leis e deveres (Pflicht) sejam mais fortemente impressionados. A vontade também é determinada pelo sentir. Os momentos da razão e da sensação são conjugados por Hegel. Não se tem a religião somente na racionalidade. Poderia essa ser uma referência a Kant? Provavelmente sim, pois, para Hegel o predomínio da razão sobre o coração ou do coração sobre a razão seriam sempre danosos. Por um lado, o homem é levado a ver o que lhe é natural como perverso e por outro como sempre condicionado pela satisfação.

Não é fácil dizer se a simples prudência ou a moralidade atual é a base determinante da vontade. Assegurada que a satisfação de nossos instintos para a felicidade é a maior meta de nossas vidas, se nós soubermos, porém, pelo menos calcular bem o suficiente, os resultados aparecerão exteriormente tão bons quanto são regidos pela razão (HEGEL, 1993, p. 84).

Hegel vai aqui numa direção diferente de Kant, pois este último delimita claramente o campo da razão, da moral, dos sentidos e da religião. Para Kant, a moral independe da religião, mas esta não se pode dissociar da moral, sob o preço de se falsear. Já para Hegel, a própria moralidade adquire pela religião uma maior e melhor fundamentação, pois os mesmos impulsos naturais e sensíveis que fazem parte do ser da religião não são aqui deixados ao sabor dos ventos e podem fazer o ser moral mais efetivo. Apesar disso, insiste Hegel, que as motivações para o bem agir efetivam-se sensivelmente e que uma religião efetiva é também necessariamente sensual. Uma moralidade movida e nutrida pelo sensível e uma religião que não repudia a sensualidade tornam-se comprometidas com certas preferências. O envolvimento se dá movido por interesse e isso exprime uma oposição à incondicionalidade da moral kantiana. Hegel reconhece que impulsos morais perdem sua dignidade ou valor por serem impulsos, mas, por outro lado, revelam o homem enquanto tal que também se perde se se restringe à ação da fria razão. Portanto, não se pode deixar de pensar aqui na incondicionalidade do agir moral em Kant que prescinde de toda e qualquer motivação sensível. $^{2}$

$\mathrm{Na}$ medida em que se fala de uma religião pública, trata-se de se considerar o processo de formação do povo que a contém, pois a religião deixa de ser tão somente crença e passa a representar a própria compreensão do ser humano, no qual razão e sentimento estão presentes. A religião que assume a história se torna prática institucional do que e de como o homem se realiza enquanto tal.

A prática institucional é uma forma de efetivação e como tal Hegel aponta o fato histórico de que a religião cristã teve sua doutrina alterada ao longo do tempo, às vezes até ao custo de se tornar geradora da escuridão, para aparecer então como luz (HEGEL, 1991, p. 86). Hegel reconhece que a religião cristã em seus primórdios não deixou de sofrer as influências de seu tempo muito embora possa ter procurado beneficiar-se dos acontecimentos.

Por outro lado, há uma religião popular presente no instituído, além do qual ela também se projeta. Ela se caracteriza por ser sensível e pelo grau de sua força em influenciar o comportamento. Seu espírito se perderá na medida em que se aprisionar em suas correntes ou idéias religiosas que não garantam sua força juvenil. Se a religião não pode apoiar-se unicamente nas sensações, ela igualmente não pode ser unicamente razão pensante ou intelectualizante.

O gênio, espírito, jovem de um povo é fogoso, cheio de vida e movido por interesses que substituídos pela formalidade e pela formalização iniciam seu envelhecimento.Aqui pode-se pensar na contraposição entre o dever ser e o ser aí já efetivado.

\footnotetext{
2 “Aqueles aos quais não parece ser suficiente o simples princípio formal de determinação - aquele da conformidade com a lei como princípio de determinação no conceito do dever, confessam, no entanto, que não pode ser encontrado no amor de si que só tem em vista o bem-estar particular." (KANT, 1992, p. 13).
} 
Quando falamos de religião como pública nós incluímos os conceitos de Deus, de imortalidade assim como tudo o que se conecta a eles, mas especificamente na medida em que tais temas constituem as convicções de todo um povo, influenciando suas ações e seu modo de pensar. Incluímos também os meios pelos quais um povo é ensinado e as idéias penetram seu coração; meios esses que não se restringem somente ao imediato, mas que projetam para além do presente (HEGEL, 1991, p. 86).

Nesse ponto, Hegel coloca a religião, objetiva, instituída, e a subjetiva, informal em relação uma com a outra.

A religião objetiva é a fé que crê tendo no entendimento e na memória suas forças, que realizam, que promovem o conhecimento, consideram o pensar, e mantém ou acreditam para que a religião objetiva se torne prática. No entanto, o entendimento e a memória acabam por ser um "capítulo morto" (HEGEL, 199, p. 87), à medida que a religião objetiva deixa-se ordenar na cabeça das pessoas, ser posta em sistema, apresentada num livro e exposta numa conversa. A praticidade da religião objetiva é um mero transplante intelectual. Sua exteriorização é tão somente ser exterior dissociado do interior ou dissociação do exterior que não é em si senão o que deve ser suprimido. Por isso, ela segue a ordenação analítica do deve ser e não do próprio ser que também é não ser. "A religião objetiva pode também possuir conhecimento prático, mas somente como um tipo de capítulo congelado. É suscetível a esquemas organizacionais; pode ser sistematizada, posta em livros e exposta discursivamente." (HEGEL, 1991, p. 87).

Areligião subjetiva exterioriza-se pelas sensações e atitudes. A forma não trai o conteúdo que abarca. Aquele que aqui tem religião não possui grande conhecimento religioso, mas sente intensamente a presença de Deus. "Se digo de alguém que ele tem religião isso não significa que ele é bem instruído, mas muito mais que seu coração sente a presença ativa, a maravilha, a proximidade da divindade que seu coração conhece ou vê." (HEGEL, 1991, p. 87). É uma religião viva que se efetiva em sua essência interior e na efetividade exterior. Essa mesma religião é, segundo Hegel, individual e almeja a abstração, pois, diante do livro da natureza (ROUSSEAU, 1994, 1995), marcado em toda a sua extensão pela variedade e pela diversidade, ela reduz isso tudo a uma unidade amistosa e convergente. Desse modo, uma religião de caráter popular se caracteriza por falar à todas as dimensões daquele que crê, afirmando-se na totalidade do real. Assim, a universalidade de um princípio, por exemplo, como o dever ser, somente se confirma enquanto tal se reúne em si a diversidade, mas não a reduz a si.

Os inúmeros conhecimentos religiosos pertencem ao contexto da religião objetiva, porém também se ligam à religião subjetiva na qual sofrem alterações. $\mathrm{O}$ quanto à religião subjetiva se deixa influenciar pela objetividade dos conhecimentos permanece uma questão porque o determinante é a forma de apreensão sensível ou como os órgãos dos sentidos se constituem. De certa forma, pode-se sugerir aqui uma certa arbitrariedade dos sentidos que, por sua vez, confronta a indiferença da razão diante das motivações sensíveis. (KANT, 1997). Não adianta submeter ou pretender submeter os sentidos à razão. Eles não deixam de ser o que são. Aliás, o empenho em suprimi-los sustenta ainda mais sua ação. "É a totalidade dos princípios religiosos e dos sentimentos que brotam daí, acima de tudo o grau de força com os quais estes são capazes de influenciar modos de ação, que é decisivo numa religião popular." (HEGEL, 1991, p. 87-86).

A religião objetiva é ensinada já na infância e, enquanto se mostra nas formas institucionais, o conhecimento religioso é impresso e guardado na memória.

Ao contrário da religião que interfere para direcionar e para corrigi, Hegel envereda pelas idéias de Rousseau e enfatiza que a natureza garante a cada homem uma semente do melhor, da moral que emerge dos sentimentos e das sensações, mas 
vingam através da educação, da cultura. Não se pode deixar de reconhecer aqui uma distinção em relação ao Kant da "Religião nos limites da simples razão", para quem o bem é uma tendência 'natural' do homem racional. A aproximação de Hegel da perspectiva de Rousseau afirma a origem sensual do bem. Contudo, Hegel parece muito mais preocupado com a presença do bem no mundo sensível do que fundá-lo somente aí.

Eu não tenho a intenção de investigar quais ensinamentos religiosos tem o maior interesse para o coração ou podem dar à alma o maior conforto e encorajamento, nem como as doutrinas de qualquer religião em particular devem ser constituídas, ou ainda se elas devem fazer as pessoas melhores e mais felizes. Minha preocupação é muito mais com o que deve ser feito de modo que a religião com toda a força de seus ensinamentos poderia ser produzido na fábrica dos sentimentos humanos, ligados com o que nos faz agir e mostrar ser eficaz possibilitando, assim, a religião tornar-se inteiramente subjetiva (HEGEL, 1991, p. 92).

A religião não lança raízes sem que haja um solo propício para tanto. Nesse sentido, a religião não se antecipa à existência, mas surge a partir de condições que a possibilitem. A sensibilidade moral talvez se expresse em seus níveis rudimentares do instinto pelo agradável e pelo desagradável tendo aí momentos constitutivos de seu ser. Teria a moral suas fundações no natural? Há bons indícios aqui, em Hegel, para tanto. Cabe, de passagem, a menção de que há uma diferença entre Kant e Hegel para quem a fonte da moral não é um fato da razão. Em relação à moral e à natureza, Hegel começa a promover uma aproximação entre ambas, e isso se coaduna com a centralidade do tema da vida que começa a ganhar espaço em seu pensamento e que aparecerá nos textos do período de Berna. A natureza humana é uma humana natureza na qual e pela qual o homem aprendeu-se e, de igual modo, veio a conhecer a divindade.
Pode muito bem ser que a idéia de um ser poderoso, e invisível lançou raízes na alma humana por ocasião de algum fenômeno natural amedrontador. Deus pode ter se revelado inicialmente através do clima que fez com que alguém o sentisse mais perto, por exemplo, no soprar da suave brisa noturna. De qualquer forma a alma humana eventualmente experimentou um sentimento moral tal que a idéia de religião alguma coisa respondeu às suas necessidades. (HEGEL, 1991, p. 92).

Uma diferença importante, para Hegel, entre religião subjetiva e objetiva é que a segunda é matéria da teologia, pois é o campo do entendimento intelectual. Obviamente a religião subjetiva não fica isenta da ação da teologia, mas sua característica é a razão prática que não se detém sobre o dogma ou as questões envolvendo o conhecimento de Deus, mas mesmo assim é possível um conhecimento de Deus nas práticas privadas. Essas padecem, em certa medida, de uma dada arbitrariedade, porém assumem necessariamente uma determinação. Por um lado, nenhuma determinação realiza o divino. Por outro lado, a ausência da determinação permite a manifestação indiscriminada do ser aí ou do que possa caracterizar, por exemplo, o divino ou o comportamento adequado.

Para Hegel, a religião objetiva merece consideração porque revela a subjetiva. "Falo de religião objetiva somente na medida em que ela também enquanto tal revela a si mesma como um componente da religião subjetiva." (HEGEL, 1991, p. 3-4).

\section{Religião Subjetiva ou o Calor do Sensível}

Nesse sentido, afirma Hegel, que seu interesse é a religião vivida e não necessariamente ciente de si, mas que se espalha e está presente em todos os campos da atividade humana. A subjetividade religiosa apropria-se da objetividade da doutrina, pois faz com que essa assuma os moldes do cotidiano. A religião subjetiva guia-se pelo que é e não pelo que deve ser. Nem por isso sua orientação 
é imediatista, pois são as exigências do vivido a cada momento que determinam ou indicam para ela o ser. Hegel confronta com tal perspectiva a interioridade da religião em Kant. O dever (Pflicht), para Hegel, que convence à prática do bem advém da promoção pela razão prática na crença em Deus e na imortalidade.

Hegel parece aderir aqui à idéia kantiana de que a moral se antecipa à religião, porém sugere também que as manifestações sensíveis foram desde o início as motivações para a percepção de uma essência invisível. Então, a questão da dedução da religião (FICHTE, 1964, p. 2-3) sugere um novo divisor de águas entre Kant e Hegel.

Curiosamente no parágrafo seguinte das páginas 91-92 do texto em questão, segundo a edição crítica, Hegel entende poder identificar a religião com a magia, se suas bases são tão somente sensíveis.No entanto, cabe verificar se a religião 'tão somente' tem bases sensíveis! Ele reconhece aí, no sensível, uma consciência do divino que regula as relações com o mesmo divino e entre os indivíduos. $\mathrm{O}$ componente moral exigiria um nível de apreensão mais elevado do qual o sensível parece carecer.

A religião objetiva manifesta a riqueza de sua expressão pela gama de doutrinas historicamente desenvolvidas e a subjetiva manifesta a sua unicidade, pois a religião é questão do coração, isto é, de acordo com o que significa para aquele que crê. A intimidade da crença parece unir, enquanto que a exposição da doutrina parece separar. Curiosamente Hegel critica aqueles que colocam a religião na organização sistemática doutrinária ou que se ocupam em transformar o calor da fé na frieza das palavras pela teologia. O conhecimento frio (kalte Erkenntnisse), expressão empregada por Hegel, parece novamente mirar Kant na medida em que a religião kantiana abandona o calor (Herzlichkeit) daquele que crê. Hegel cita Nata, o sábio de Lessing (LESSING, 2008 - Bd. 3, 139, Vers. 690692) no sentido de aproximar a religião subjetiva e a objetiva, pois a motivação ou a fonte deve ser a mesma. A religião é coisa do coração que não se dissocia da totalidade das experiências vividas que os dogmas, o entendimento e a memória não abarcam somente em si.

$\mathrm{O}$ entendimento não proporciona à religião senão o seu arrefecimento, pois o entendimento racionaliza a religião de modo a torná-la uma abstração intelectual. Para Kant, a moral não precisa da religião (KANT, 1997, p. 13), pois é algo próprio do homem. Assim, a religião será tanto mais eficiente se assumir a realização do que já está implantado no homem e orientar-se pela necessidade racional independente de qualquer objetivo. Aparentemente, Hegel parece enaltecer as manifestações externas da religião, pois elas denotam que se trata de vivenciar o religioso.

A grandiosidade do entendimento, Hegel a reconhece, reside na aproximação do vivido conforme é e não como se gostaria. Do contrário, o que se tem é o afastamento da vida por meio do raciocinar puro. No entanto, o entendimento também se afasta do vivido na medida em que projeto sobre este como proceder, o quê fazer não se deixando influenciar pelas exigências do imediato. Nesse sentido, Hegel menciona personagens da Grécia antiga que não se deixavam levar pelas vitórias e a euforia provocada pelas mesmas, pois procuravam conciliar os festejos com a lembrança das perdas ocorridas. Evoca-se, aqui, a idéia do equilíbrio entre o entender e o sentir de modo que a realidade pudesse, assim, ser melhor compreendida. Os exemplos citados por Hegel têm o aspecto controverso em relação ao entendimento que não pode ser abandono do interesse imediato sob o preço de erguer a partir daí um mundo tão somente caracterizado pelo desejado.

Para Hegel, não se pode deixar de reconhecer a beleza presente nas manifestações de fé cuja motivação se encontra muito mais na simplicidade dos sentimentos do que na crítica calculada do entendimento. Por isso, saber mais é também sentir mais e sentir mais conduz ao saber mais. 
Não é sem razão que Hegel caracteriza, por exemplo, a falta de amor pela submissão do coração ao entendimento na medida em que o que se faz ou deve ser feito necessita passar unicamente sob o crivo da racionalização. Faz-se necessário situar a razão no interior dos conflitos existenciais e, a partir daí, obter a avaliação que se põe como necessária. Hegel identifica a falta de amor com a falta de experiência que pode não estar num tratado de moral, porém cabalmente presente nos erros de um governante, isto é, o dever ser está no ser ou no que é enquanto tal, ou ainda, no realizado. A experiência sensível, a participação nos acontecimentos do cotidiano não pode ser simplesmente suplantada nem negligenciada por toda e qualquer compreensão que se pretende lúcida e esclarecedora.

\section{O Iluminismo: a Vontade para Efetivar Através do Entendimento}

Para Hegel, o entendimento é muito útil à religião objetiva, porque elucida e sistematiza os princípios doutrinários e faz por merecer aí os melhores elogios. Contudo, o entendimento não consegue sozinho, segundo Hegel, tornar prático o que é compreendido.

$\mathrm{O}$ entendimento faz o que é conveniente àquele que o conduz: ele pode mudar o agradável em desagradável ou vice-versa, enfim, faz o que quer. A edição crítica aponta aqui uma possível fonte dessa abordagem hegeliana. Rousseau do Discurso sobre a origem e os fundamentos da desigualdade entre os homens "[...] a razão engendra o amor próprio. A reflexão o fortifica.” (ROUSSEAU, 1978).

Segundo Hegel, o entendimento pode tornar o homem mais inteligente, mas não melhor. A virtude não pode ser reduzida à inteligência. Esta, sem dúvida, pode ajudar, porém ela não garante efetividade.

Uma inteligência ou entendimento esclarecido não se torna garantia de atitudes aceitáveis e o melhor tratado de moral não estabelece a efetivação da moral. Por outro lado, que o homem se guie pelo seu entendimento também não lhe garante a certeza da atitude moral, pois ele pode agir como uma máquina fria que não presta conta ou não considera ninguém.

A idéia de esclarecer alguém, segundo Hegel, parece significar remover os preconceitos existentes e, de forma localizada, Hegel parece ver o esclarecimento (vide iluminismo) dirigido particularmente à religião como se aí grassassem todos os preconceitos. O esclarecimento aponta a filiação ao sensível como a fonte de preconceitos, pois o crente acredita que o efeito será produzido por uma causa alheia ao mesmo. No entanto, Hegel também adverte que o preconceito habita a certeza da sucessão causa-efeito (Hume?), pois desconhece as intermediações entre causa e efeito. Se a sensação e a fantasia contribuem para o surgimento e a proliferação de preconceitos, então cabe saber, ressalta Hegel, que falsas noções e noções verdadeiras, não aceitas como tais, podem estar presentes para além dos "limites da simples razão"! Contudo, Hegel não está empenhado em contribuir para um pensar puro e livre de erros, mas em questionar o que e quem (como) determinar a verdade como referência.

Apesar disso, reconhece Hegel, há princípios universais que norteiam as religiões, mesmo aquelas que tenham sofrido alguma deformação, pois o conhecimento humano tomado sobre as religiões exige o reconhecimento de sociedades estruturadas por trás das crenças.

Os princípios existentes contradizem o desejo sensível das pessoas que podem guardar na memória esses princípios, porém eles não são necessariamente significativos. Hegel os qualifica como universais e abstratos. A formalidade de um princípio que não fala ao coração não se torna efetivo.

Uma religião efetiva, acessível, é aquela que rompe os limites da universalidade racional e assume a forma do mandamento sensível (Sinnlichkeit annehmlich seyn sollen). Não basta a adesão 
movida pela razão, mas é também necessária a adesão pela aceitação de que Deus exige, sendo essa exigência assumida pelas pessoas como motivação para o agir. Desse modo, não basta somente a objetivação racional, mas também é necessário o reconhecimento interiorizado, ou seja, a motivação sensível que atua sobre as pessoas. Portanto, não se trata simplesmente de separar razão e sensação na religião. Hegel insiste na religião que fala à vida de um povo que resulta na conduta que ele adota e adotará. Para tanto, a religião não pode falar somente pela razão via entendimento.

Daí, indaga Hegel, quanto a reflexão ou o raciocinar pode entrar no terreno da religião, que é questão do coração, sem que eles causem a perda da "razão da fé". O entendimento, sugere Hegel, pode promover uma devassa, porque se guia por interesses que o fazem senhor. Ele é capaz de racionalizar todas as paixões e encontrar uma justificativa para sua contenção, mas nas situações de crise o entendimento (Verstand) é rapidamente abandonado, pois a premência da necessidade se impõe como determinante.

O que parece harmonizar com a religião não é a racionalização, nem o esclarecimento, mas a sabedoria, que não é ciência, mas que se nutre das opiniões e experiências sem que faca concessões a interesses arbitrários. Seria a figura de Sócrates que na praça apreende o conteúdo de suas considerações evocado aqui por Hegel?

A disposição da mente pelo entendimento esclarecido não promove a moralidade no homem devido ao cálculo frio de suas indicações. O bem, a bondade, e a pureza de coração são infinitamente superiores. Seria aqui Hegel acometido por uma visão romântica? Sua crítica ao imperativo kantiano desprovido de condicionamentos conteudistas não seria extremada de modo a se fazer sentir? Talvez seja difícil aceitar a preferência pela bondade e pela pureza e aí pode residir a perspectiva hegeliana, isto é, de que o entendimento pode ser tão efetivo quanto o que parece estar despojado dele.
Hegel parece ilustrar sua crítica ao entendimento que aparelha o indivíduo para uma vida boa com a referência ao texto de J. H. Campe "Theophron" (HEGEL, 1991, p. 565, Am. 94, 28), que se assemelha a um livro de auto ajuda pelo qual o jovem é convidado a se disciplinar furtando-se ao contato com o que possa afetá-lo. Hegel parece apontar na direção do envolvimento com as coisas para, a partir daí, desenvolver a disciplina. Os problemas não podem ser simplesmente evitados, pois eles surgem da imersão ou da exclusão absolutas ou da negação da relação.

Por isso, para Hegel, o entendimento carece de sabedoria, pois se deixa aprisionar pela particularidade do conhecimento esclarecido e abandona a também efetividade do conhecimento popular. Os livros, por exemplo, empanturram e impedem que a vida possa fluir.

Uma das atividades do entendimento é refinar a religião objetiva, porém ele perde sua forca ao considerar o melhoramento humano, ou seja, ao associar como determinante sua ação para a promoção do humano. $\mathrm{O}$ entendimento não garante o estabelecimento do bem, mas tão somente sua possibilidade lógica e sua necessidade lógica. O entendimento peca por não fazer com que o homem se veja no divino, expressão maior do bem.

O que se sabe e se diz do divino é que o que o homem sabe e diz. O que ele sabe e diz é algo espantosamente grande e complexo. Uma elaboração como essa já não pertence a um indivíduo, porém cada um deve assumir a estrutura para si e fazê-la sua moradia. Aqueles que simplesmente herdam deixam de viver e se tornam formalistas, pois não reagem senão como receptores. Viver a estrutura já existente é participar dela de modo a não somente reconhecê-la, mas também de se reconhecer nela. Desse modo, pode-se indagar, conforme Hegel, qual a possibilidade da religião.

Como, sustenta Hegel, pode-se conseguir que a religião seja assumida sem se tornar mercado de troca e também sem se tornar uma atividade racional 
formalista? Sobre o segundo aspecto, é bastante claro que Hegel tem aqui Kant em mente. Para Hegel, o homem precisa muito mais de motivos do que da disposição de respeito para com a lei moral.

Por trás da seguinte argumentação hegeliana, há um debate com o Kant da "Crítica da Razão Prática". Agir conforme a razão que nos impõe princípios parece ser sobre-humanos. Para Hegel, de fato eles o são, porém isso não significa que não se deva ir nessa direção. No entanto, isso significa desconhecer a natureza humana que é dependente das sensações. Há sentimentos humanos que devem ser cultivados, pois eles são também uma resistência contra o inaceitável. O amor, por exemplo, tem interesses menores que constroem os maiores, mas nem sempre se orienta pelo que deve ser.

Apesar da perspectiva apenas mencionada, a prática empírica é vista por Hegel como incapaz de lançar as bases para princípios fundamentais. No entanto, Hegel reconhece que para que os homens sejam atingidos de fato, deve-se fazer uso de todos os expedientes empíricos quantos forem possíveis, pois é assim que eles poderão ser alcançados sem que a liberdade dos mesmos seja cerceada, nem que os sentimentos evocados devam significar qualquer rebaixamento.

\section{A Superação do Dualismo na Religião}

Para a religião popular, torna-se vital a conjugação coração-fantasia (KANT, 1992, p. 196198), que caracteriza importante parte do homem. Não se pode deixar esse aspecto a mercê de qualquer conteúdo arbitrariamente escolhido. Também não se pode delegar ao entendimento a tarefa de prover o conteúdo, pois ele não se motiva senão pelas abstrações que sem a empiria se caracterizam pela pobreza de compreensão do todo da realidade. "[...] é pouco provável que a inteira humanidade ou um único indivíduo possa viver privando-se de procedimentos não morais." (HEGEL, 1991, p. 101).
A diferença entre religião popular e religião privada reside, para Hegel, no objetivo de cada uma. A religião popular nutre a imaginação, o coração e a alma à prática da virtude. A religião privada sustenta para a prática dos deveres, conforto no sofrimento dos indivíduos. Os motivos para tal caracterização são os seguintes:

- A prática da virtude e do dever pode ser apoiada pelos homens de experiência e altamente qualificados ou pela autocomunicação que resultaria da influência de uma religião pública. Contudo, a prática doutrinária da virtude $\mathrm{e}$ seu ensino podem ser tediosos. Poderia isso caracterizar o dever ser?

- Se a virtude não brota da doutrina e da retórica, então se deve tomá-la como uma planta que cresce livremente, pois se cuidada demais o dano será maior do que se for deixada por conta (HEGEL, 1991))

Parece mais adequado não interferir, nem ditar como proceder, pois isso tende a saturar as pessoas. Há mais esforço para levar ou trazer as pessoas até Deus do que fazê-las perceber que elas já se encontram nele.

Daí, o que importa é a confiança em Deus. A confiança em Deus reside em contar com ele e em contar para ele, ou seja, não há um estar fora de Deus. Trata-se do todo que abarca tudo e que tudo considera assim como, por exemplo, o sofrimento e a dor.

Agora cabe considerar a questão hegeliana de como deve ser constituída a religião popular. A religião popular é aqui tomada em sentido objetivo

a) em relação à religião objetivamente dada;

b) em relação às cerimônias.

A) I Sua doutrina deve ser fundada na razão universal:

II fantasia, coração e sentidos não devem ser desprezados;

III deve tratar do todo da vida, também suas necessidades. 
B) o que evitar?

Toda superstição, principalmente contra o iluminismo ${ }^{3}$.

A doutrina da religião popular deve se fundamentar sobre a razão mesmo que sustentada por uma revelação divina, pois ela deve ser assumida pelo homem como algo que ele quer e no qual se reconhece, assim como ao seu mundo. Trata-se da superação do postulado kantiano no qual a fé e suas correlações pertencem ao campo da metafísica? A religião popular fala não somente à fantasia, mas principalmente à razão imanente. A universalidade da razão permite a tolerância contra a regionalidade da fantasia. Não se trata de se prender nem de se limitar ao aqui e agora, mas de não se perder no aquém nem no além. A razão deve, sim, porém ser engajada no mundo em sua cotidianidade.

A força da doutrina, enquanto tal, reside em sua simplicidade e quanto mais simples ela for maior será sua influência sobre as pessoas. Ela será compreensível e impactante pela mediação da própria existência, pois é e deve ser o que ela exprimirá.

Desse modo, a doutrina se dirige necessariamente ao homem e se relaciona com as práticas nobres já existentes sendo a promoção das mesmas. O que é altamente humano também deverá ser tomado como a estatura do próprio Deus. Hegel reconhece aqui a dificuldade de se confrontar o que os homens têm aprendido como, por exemplo, a dicotomia entre o divino e o profano. Nesse sentido, uma doutrina que pretenda o alcance popular necessita construir pontes entre os homens e Deus de modo que a divindade possa ser conhecida e reconhecida na humanidade e esta, por sua vez, também se conheça e se reconheças mais e melhor na divindade. Uma doutrina que fala ao povo precisa falar também a partir do povo.
A fé da comunidade cristã expõe um Deus transcendente que se encontra além da comunidade precisamente por atestar a sua proximidade, mas não o seu ser com a comunidade.

A insistência no pedir, a certeza do receber afirma o que vem de fora e não o que já está presente. O homem permanece um reflexo de Deus e não o seu espelho.

A doutrina que falha em reunir o divino ao humano pode resultar na aceitação do sofrimento até como algo desejável A positividade do ser religioso deslocaria a alegria de viver nesse mundo para o outro mundo e ainda identificaria isso com a vontade de Deus.

Hegel compara a fé cristã com a fé grega e aponta o fato de que para os gregos os deuses favorecem uns e abandonam outros seguindo sempre as leis morais e o que ocorre em termos de sofrimento não é mais do que sofrimento de acordo com a natureza e seu ritmo. Não é questão de interpretação, mas de reconhecimento de si no que lhe sucede.

As doutrinas simples fundadas sobre a razão universal são compatíveis com a educação popular. A educação afeta a doutrina principalmente no que diz respeito aos aspectos exteriores. A religião se interioriza não porque se retrai do mundo, mas porque deixa de ser imposição do mundo para ser imposição no mundo.

As doutrinas que se fundamentam na formalidade da razão humana sustentam-se por si mesmas, isto é, pelos seus motivos racionalmente formais e pelas cerimônias que evocam igual perspectiva. Elas não podem se envolver com a realidade civil senão formalmente e a positivação de suas intervenções segue o querer do dever ser e não o dever do querer.

Hegel insiste no fato de que toda religião que se pretende popular deve levar em consideração o coração e a fantasia, pois a mais pura e racional

3 Hegel chama aqui a atenção para o fato de que as contribuições do iluminismo não podem ser simplesmente desprezadas e que os avanços da razão não podem ser confundidos com a mera oposição à religião. 
perspectiva somente se tornará a alma e o corpo de um povo se assumir o que é desejado e sonhado. A religião cristã está, em sua maior parte, ligada à história e aí tem sua representação. Estando no mundo, ela encontra aí o lugar profícuo para a imaginação. Se uma religião procura mover as pessoas ela não pode pintar o mundo tão somente com uma única cor. As cerimônias podem ajudar nisso, mas não raramente são tomadas como a essência.

O batismo e a eucaristia, por exemplo, segundo Hegel, são elos na comunidade para uma vida mais perfeita e moral, mas, se tomados para provocar sentimentos piedoso eles não passarão de cerimônias. Estas estruturam o que é essencial, sendo compostas por uma dada forma que abarca um dado conteúdo. Numa religião intencionalmente popular forma e conteúdo apresentam-se como complementares.

As cerimônias também evocam o aspecto do sacrifício que caracteriza uma exigência no estabelecimento e sustento da comunidade.

Os sacrifícios são de dois tipos:

a) os destinados a abrandar a ira divina por ter agido: contra moralidade ( pois se buscou a fuga dos compromissos não honrado)s ou para obter um favor em seu benefício. Esses expedientes, para Hegel, podem ser facilmente criticados e identificados com uma atitude moralmente equivocada e não aceitável. Mesmo assim, Hegel salienta o aspecto positivo que envolve a obstinação daquele que se impõe o sacrifício. A justificativa racional não está ausente na prática do sacrifício, porém é a carga de sentimentos que leva o crente a agir com paixão.

b) o sacrifício feito para agradecer e honrar a divindade incondicionalmente, da qual se sabe dependente.

Para que possam ser vivas, as idéias de sacrifício são mais efetivas se originárias do espírito de um povo do que da religião, pois se fundadas somente na religião podem passar a ser caracterizadas pela formalidade, pela frieza e artificialidade. Isso pode ser relevante para a religião privada, porém não o é para a religião popular, cujo alcance é um dado povo. A eucaristia foi, conforme Hegel menciona, no início, posta como momento de festa da comunidade e não como cerimônia.

Então, o que a religião popular tem como características em suas cerimônias seria:

c) evitar os fetiches e a mecanicidade, e buscar intensificar o sentimento piedoso do povo para o qual a música sacra e festas populares concorrem.

\section{Conclusão}

Quando a religião e a vida se separam, provavelmente as exigências religiosas não contemplam ou desfiguram as necessidades básicas da vida. A religião popular é aquela que se encontra no povo e este se reconhece nela. Mesmo nos exageros a religião popular se faz presente não deixando o exagerado à própria sorte. A religião popular tem como crente ideal o crente real. O conteúdo não é somente o que deve ser, mas o que é.

A religião popular caminha lado a lado com a liberdade se promove grandes e nobres sentimentos.

Hegel avalia a religião de seu tempo como o deslocamento do homem de seu mundo aprendendo a ver o que vive com olhos de lamentação. A fraternidade não é celebrada, mas tolhida diante do sagrado.

A história, a religião e o grau de liberdade política constroem o espírito de um povo. São três aspectos interdependentes. $\mathrm{O}$ que é individual precisa integrar-se ao todo do espírito. A religião mobiliza muitos e somente com muitos a totalidade pode se realizar. As práticas históricas são os conteúdos do espírito de um povo.

O pai desse gênio é o tempo, cuja vida permanece em única dependência, a mãe a polis, a constituição sua mãe adotiva, sua ama a religião e jamais separado da terra que o nutre e na qual é nutrido. 
Daí, a religião nutre o homem como ama seca que não o restringe, mas revela a magia da existência.

A religião verdadeira nutre o homem livre e maduro que não se furta à pureza das sensações nem se perde no misticismo.

Hegel compara a religião com uma ama seca grega que após concluir seu trabalho permanece na família e a ela, ama seca, o nutrido sempre retorna, mas não mais como dependente e sim como tendo gratidão e amor. A religião continua sendo uma das mais importantes situações na vida!

Ao espírito pertence à totalidade e sua saída da determinação, para que se torne o todo, não é o abandono desta, mas a efetivação da sua maturidade, isto é, do reconhecimento de si no que não é mais um distinto, mas sim um outro de si. O espírito não somente quer, mas quer algo e se quer nesse algo no qual se sabe e se sente.

\section{Referências}

FICHTE, J. G. Versuch Einer Kritik aller Offenbarung. In: LAUTH, Reinhard; KANS, Jacob (Ed.). Werke 17911794 Band 1. Stuttgart-Bad Cannstadt: Bayerischen Akademie der Wissenschaften, 1964.

HEGEL, G. W. F. Frühe Exzerpte Text 16. In: NICOLIN, Friedhelm (Ed.). Gesammelte Werke Band 2. Hamburg: Felix Meiner Verlag, 1991.

. Frühen Schriften. In: MOLDENHAUER, Eva; MICHEL, Karl Markus (Ed.). Werke Band 1. Frankfurt am Main: Suhrkamp, 1970.

KANT, I. A religião nos limites da simples razão. Lisboa: Ed. 70, 1992.

Crítica da razão prática. Lisboa: Ed. 70, 1997.

LESSING, G. E. Nathan der Weise. Werke Band 2. München: Verlag Klatt, 2008.

ROUSSEAU, J. J. Discurso sobre a origem $e$ os fundamentos da desigualdade entre os homens. São Paulo: Abril Cultural, 1978.

. Emílio ou da educação. São Paulo: Martins Fontes, 1995.

1994. . Júlia ou a nova Heloísa. São Paulo: Hucitec,

Recebido em: maio 2010

Aceito em: julho 2010 